\title{
New Findings of Pathogenesis, Diagnostics and Control of Paratuberculosis in Cattle
}

\author{
M. PAVLAS \\ State Veterinary Institute, Brno, Czech Republic \\ Received May 17, 2004 \\ Accepted March 3, 2005
}

\begin{abstract}
Pavlas M: New Findings of Pathogenesis, Diagnostics and Control of Paratuberculosis in Cattle. Acta vet. Brno 2005, 74: 73-79.

Mycobacterial enteritis in cattle described as paratuberculosis can be caused apart from Mycobacterium avium subsp. paratuberculosis by other subspecies and variants of Mycobacterium avium which play a less important epizootiological role. Failures to control paratuberculosis in cattle are mainly due to incorrect assumptions that the main source of infection are adult individuals older than 18 months in preclinical and clinical phases of the disease. Presently, bacteriological examination of faeces by culture is considered to be the most reliable method for intravital diagnosis of paratuberculosis. The main disadvantage of this examination is the long time span necessary for the final evaluation of the samples. In recent years we were able to obviate this problem by introduction of separation bacterioscopic method. This method enables to identify the animal shedding mycobacteria in cattle herds within several days of faecal sampling.

In the years 2000-2003 we examined animals at 18 farms with 3620 head of cattle. In six farms paratuberculosis was diagnosed using separation bacterioscopy, standard culture and PCR to determine the sequence IS 900 method. This study revealed that calves infected during the first weeks of life can be a frequent and important source of infection as soon as at the age of several months. In herds with poor control measures implemented we found massive mycobacteria shedding in faeces in 7.8 to $80 \%$ young cattle aged between 4 to 6 months.

Separation bacterioscopy completed with molecular biology method using PCR to determine the sequence IS 900 provides a reliable diagnostic tool. This method was verified using comparative tests in which we obtained $90 \%$ sensitivity with separation bacterioscopy as compared to standard culture as recommended by Office International des Epizooties.
\end{abstract}

M. avium subsp. paratuberculosis, calves, milk nutrition, faeces, shedding, pathogenesis, bacterioscopy, PCR, sequence IS 900, methods of control

In 1895 , mycobacteria differing by their biological characteristics from the mammalian ones causing tuberculosis of humans and animals, as described by Robert Koch in 1882, were found to be specific agents causing chronic intestinal inflammation. This chronic enteritis of ruminants was named Johne's disease (enteritis paratuberculosa specifica s. enteritis chronica hypertrophica bovis) after the scientist who first recognised the causative agent.

Intravital diagnostic methods were initially based on bacterioscopy and later on culture of the specific agent from faeces of the infected animal. Methods of molecular biology including the PCR test have recently been employed in the diagnostics. It was recommended to use allergic tests with johnin or avian tuberculin for the diagnosis of subclinical forms. Apart from the allergic tests, specific antibodies in the blood serum as well as milk of animals examined have been used in the diagnostics. Most problems with the diagnostics of paratuberculosis are encountered when examining infected animals that excrete the agent irregularly in milk and faeces without showing clinical signs. The diagnosis can be confirmed by autopsy which in animals suffering from progressive changes, in particular, results in finding pathognomonic lesions in the intestines visible at gross as well as histological examination. 
Paratuberculosis was considered to be a disease restricted to cattle and small ruminants only at the beginning of the last century. It was later found in other species of domestic as well as wild animals, not only ruminants but also monogastric species such as horses, pigs and rabbits, and birds. The identification of mycobacteria responsible for inflammatory changes in the intestinal mucosa resulted in the isolation of acid-fast bacteria which were growth-dependent on mycobactin and could be classified as Mycobacterium avium spp. paratuberculosis by means of molecular biology. The above-mentioned mycobacteria, however, differ frequently from bovine mycobacteria of paratuberculosis by their phenotypic characteristics as well as virulence. It means that the previous rule that mycobacteria of bovine paratuberculosis can reliably be distinguished and identified using their dependence on mycobactin is not true at present. With respect to the differential diagnostics of paratuberculosis it is necessary to be aware of the fact that cattle herds diagnosed with mycobacterial enteritis may be affected by other species, subspecies and variants of Mycobacterium avium. In some animals, however, it cannot be excluded that clear clinical signs of diarrhoea of mycobacterial aetiology are caused by less virulent variants of mycobacteria due to the occurrence of intercurrent dietetic problems, trace element insufficiency, or poor conditions of zoohygiene.

In 1987 McFaden and his colleagues recommended that the identification of the agent of bovine paratuberculosis be based on the fact that Mycobacterium avium spp. paratuberculosis contains a specific insertion sequence IS 900 in its DNA. The identification of IS 900 is currently considered decisive in confirmation of the bovine paratuberculosis agent by some authors. The above-mentioned procedure is also recommended in the Methods No. 6/2001 on prevention, diagnostics and control of paratuberculosis in cattle published by the State Veterinary Administration of the Czech Republic.

It is currently known that, besides the agent of bovine paratuberculosis, mycobacterial enteritis cases in cattle can be caused by other subspecies of $M$. avium as well as variants of the paratuberculosis subspecies which play a less important epizootiological role. Variants less virulent for cattle represent the ones described in small ruminants or other species of animals. When these less important variants of $M$. avium spp. paratuberculosis are mistaken for the bovine paratuberculosis agent and simultaneously the epizootiological situation in individual herds of cattle is evaluated incorrectly, foci of paratuberculosis may be incorrectly declared. The above facts show that current indices employed to declare a focus of paratuberculosis, if based on the isolation of mycobacteria dependent on mycobactin and identification of the IS 900 sequence only, may not be quite reliable. Erroneous conclusions, quite understandably, economically ruin the farmers, in particular.

It is a situation similar to that we have been dealing with in mycobacteria isolated from pigs and other animal species. It took, for example, several years to put through the opinion that $M$. avium spp. avium, the causative agent of avian tuberculosis, is much more important in pigs and poultry than some serotypes of $M$. intracellulare, classified as M. avium spp. avium when using the molecular biology methods. At present, respecting the above knowledge, a focus of porcine tuberculosis may be declared based only on positive findings of avian mycobacteria capable to cause organ-bound form of tuberculosis in domestic fowl after oral or intramuscular infections, whereas findings of $M$. intracellulare is not a reason to close a swine farm.

Evaluating the epizootiological situation in individual herds of cattle in relation to paratuberculosis, it is necessary, apart from bacteriological results, to consider other indicators such as the pathomorphological findings of culled animals, their laboratory and clinical data, status of nutrition, yield, and intercurrent diseases of dietetic origin, in 
particular. Prevalence and the efficacy of disease-free calf rearing can be evaluated using bacteriological examinations of faeces of young cattle between 4 to 6 months of age. The epizootiological situation can thus only be evaluated as a complex of the above-mentioned indices so that the most suitable measures to control the infection in a herd can be recommended and implemented.

\section{Current possibilities to control paratuberculosis in cattle breeds}

Even though some countries support measures to control paratuberculosis in cattle herds by considerable financial resources, the results are not satisfactory and adequate. The current state of the effort to combat paratuberculosis in the Czech Republic is similar to that of bovine tuberculosis control 70 years ago in the former Czechoslovakia. After the World War II, methods to control bovine tuberculosis were improved with much more success compared to the current state of methods employed in paratuberculosis control in this country and elsewhere.

The main difference in the control methods aimed at control bovine tuberculosis and paratuberculosis lies in the fact that every animal infected with $M$. bovis is considered to be a potential source of infection, whereas only animals found positive based on the examination of their faeces are culled for paratuberculosis. Regarding the irregular shedding of mycobacteria of paratuberculosis in faeces, limited susceptibility of culture, and a long time necessary to evaluate the culture results, the control and elimination of the infection from the herd by culture of faeces are much more difficult as compared to the control of bovine tuberculosis.

It is not necessary to stress that of paramount importance in the control of every infectious disease and also of paratuberculosis is only possible with reliable diagnostic procedures. As far as bovine tuberculosis is concerned, a considerable turn in the diagnostics of bovine tuberculosis in the former Czechoslovakia occurred in 1956 when the trivalent tuberculin was replaced by the bivalent one using new strains of M. bovis (AN5) and M. tuberculosis (PN14). Besides, biological titration of tuberculins vetus and later of purified tuberculoproteins (PPD) was developed. Both these changes increased the specificity and diagnostic reliability of allergenodiagnostics, the essential intravital diagnostic method to find animals infected with bovine tuberculosis. The sensitivity of this allergic test reached almost $96-98 \%$ in preclinical cases of cattle infected with M. bovis. Apart from standard tuberculins, the specificity of allergic tests had also been increased by simultaneous tuberculin tests which has helpful during the final period of control and post-elimination in distinguishing non-specific reactions to the mammalian tuberculin caused by atypical mycobacteria.

Comparing intravital diagnostics of paratuberculosis and bovine tuberculosis, it is necessary to say that currently there are no tests available for the diagnostics of paratuberculosis of comparable sensitivity and susceptibility to those used in the diagnostics of bovine tuberculosis by intradermal tuberculin administration. This is due to very close antigenic characteristics of the paratuberculosis agent and other avian mycobacteria which are, however, of much less epizootiological importance. The current use of combined serological and allergenodiagnostic methods in bovine paratuberculosis can be compared to the use of trivalent tuberculins prior to the whole-country campaign to eliminate bovine tuberculosis in 1956 in the former Czechoslovakia. The above-mentioned trivalent tuberculin prepared from strains of M. bovis, M. tuberculosis and Mavium caused numerous false positive reactions in cattle free from bovine tuberculosis.

\section{Materials and Methods}

In our study, bacteriological examinations for paratuberculosis was aimed at cattle herds in which animals showing changes typical of paratuberculosis at clinical examination or at slaughterhouse examination were found. 
Apart from that, faeces examinations were carried out in herds with implemented control measures, at animal trade or animals serologically positive for paratuberculosis. Thus, in the years 2000-2003 we examined 18 farms with a total of 3620 head of cattle. Paratuberculosis was diagnosed using separation bacterioscopy, standard culture and PCR determining the IS 900 sequence in six herds.

\section{Results and Discussion}

At present, bacteriological examination of faeces is considered to be the most reliable method of intravital diagnostics of paratuberculosis. However, lengthy cultivation necessary for the final evaluation of the sample is a great disadvantage of the method. Nevertheless, we have recently been successful obviate this problem by introducing the method of separation bacterioscopy which enables to find a shedding animal infected by paratuberculosis within several days of sample collection. The above method to confirm mycobacteria by separation bacterioscopy can be supplemented by methods of molecular biology, i.e., PCR to identify the IS 900 sequence. Reliability of this procedure is shown by results of comparative tests in which a $90 \%$ sensitivity was obtained using separation bacterioscopy as compared to those of standard culture recommended by OIE.

Direct finding of mycobacteria of paratuberculosis in faeces overcomes some limitations such as false negative results of culture caused by decreased growth abilities of the agent due to the use of decontamination substances, inability of some mycobacterial strains to multiply during a given incubation period due to low sensitivity of culture media and other factors. The above mentioned reasons as well as irregularity of shedding of mycobacteria in faeces are responsible for the fact that the examination by culture on a single occasion results in diagnosing only $1 / 5$ to $1 / 3$ of animals that are the source of infection (Fig. 1).

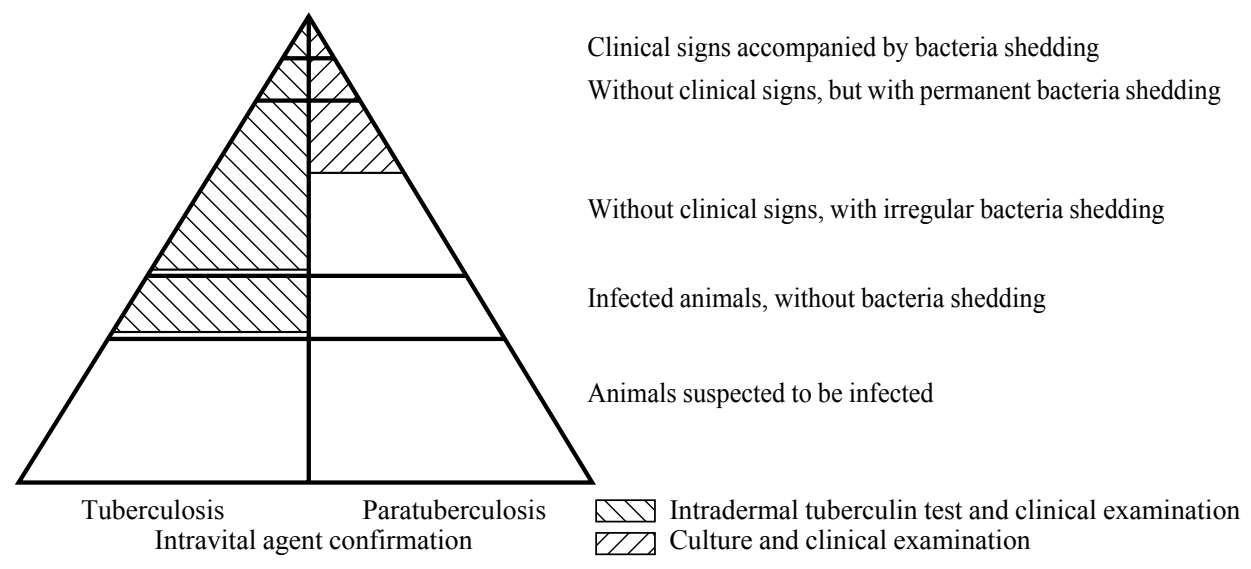

Fig 1. Intravital diagnostics of bovine tuberculosis and paratuberculosis

Animals shedding large quantities of the agent are most important for the spread of the infection contaminating the environment of stables, pastures, drinking water and bedding. Studying the dynamics and frequency of shedding of the agent of paratuberculosis in faeces as related to the post-partum period, we found the highest numbers of dairy cows to have positive faecal samples 4 to 5 months after delivery (Fig. 2). We recommend to use this knowledge in examination of the so-called risk groups of cows in implementing control measures in cattle herds, during surveillance campaigns as well as in declaring paratuberculosis-free herds. Early detection and removal of massive sources of infection as well as effective cleaning and disinfection of the stable environment and pastures play a paramount role in successful control of paratuberculosis. 


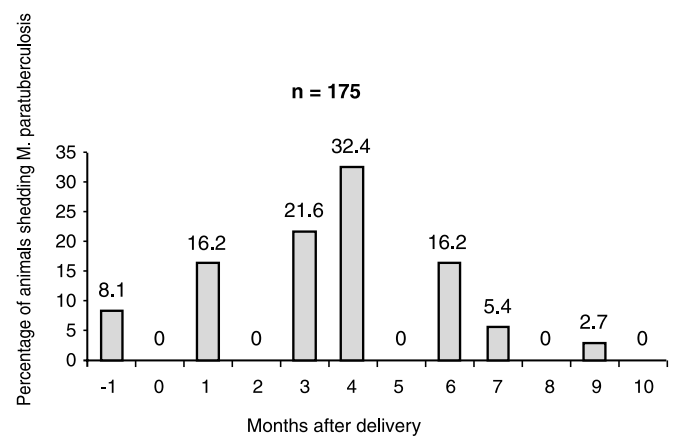

Fig 2. Shedding of $M$. paratuberculosis in faeces of cows following spontaneous infection

Failures to control paratuberculosis in cattle are mainly due to erroneous assumptions that the main source of infection are adult animals older than 18 months in preclinical and clinical phases of the disease. Our studies into the pathogenesis revealed that calves infected during the first weeks of life can frequently be an important source of infection as soon as at the age of several months. Dangerousness of these infected young animals massively shedding mycobacteria of paratuberculosis from the age of 3 months lies in the period when they are kept in hutches together with other yet uninfected individuals.

Problematic practices of calf and young cattle rearing can be documented by the occurrence of clinical paratuberculosis in young cattle and dairy cows aged 2-4 years. Success in the control of paratuberculosis can only be achieved when calves raised for breeding are kept separately from those for fattening from first days of milk nutrition. It is recommended that these measures for disease-free rearing success be verified by faecal sample examination from the age of 4 to 6 months on a regular quarterly basis.

The above-mentioned recommendations are based on our knowledge obtained during rearing calves in herds infected with paratuberculosis in which the animals were exposed to spontaneous infection by raw, non-treated pool milk from all stock dairy cows. In herds with poor control measures we found massive mycobacteria shedding in faeces in 7.8 to $80 \%$ of examined young cattle as soon as from the age of 4 to 6 months on. At the same time we found that mycobacteria shedding lasted only for several months in these animals.

In a few individuals the shedding of mycobacteria was found to be permanent and resulted in clinical paratuberculosis in some cases before sexual maturity of the affected animals. The majority of infected calves became a potential source of infection, but only some of them showed later clinically evident paratuberculosis.

As mentioned in the "Bulletin of the International Dairy Federation (IDF)" No. 362/2001, apart from faeces, milk of infected dairy cows is an important source of paratuberculosis. According to the report by 38 experts, $10 \%$ of subclinically infected cows and $50 \%$ of animals showing clinical paratuberculosis excreted the agent in the milk.

Apart from the contaminated milk, young cattle kept in rearing areas, enclosures and pastures may be the source of massive infection due to shedding the agent in faeces. Calves grown for fattening that in some herds are given raw milk during their milk nutrition can become a dangerous source of infection.

Clinical findings of paratuberculosis in young animals aged 2-to-4 years serve as evidence for their infection in rearing facilities at the age younger than 6 months. From the study of pathogenesis and diagnostics of paratuberculosis it became clear that, with respect to the control and elimination of paratuberculosis from infected herds, prevention of infection of calves immediately after birth and during milk nutrition as well as in rearing facilities for 
young cattle is much more important than elimination of dairy cows shedding the agent in faeces only on occasion.

\section{Conclusion}

Apart from the causative agent of bovine paratuberculosis, i.e. Mycobacterium avium spp. paratuberculosis, mycobacterial enteritis cases can also be caused by other subspecies of $M$. avium occurring in various other animal species, but having less epizootiological importance.

Success in the control and elimination of the infection from herds is only possible by means of achieving disease-free rearing of calves and young cattle. Even though calves are kept separately and fed heat-treated milk or milk substitutes, in herds that are being under control measures there is still the danger of the young becoming infected by raw colostrum. Rapid elimination of sources of infection such as young cattle aged 4 to 6 months is possible by means of a separation bacterioscopic method which can identify sources of massive mycobacteria shedding within several days of sample collection. The above-mentioned method results in $90 \%$ sensitivity. In combination with the PCR examination the specificity is also satisfactory as compared to the standard culture recommended by OIE.

\section{Nové poznatky o patogenezi, diagnostice a ozdravování chovů skotu nakažených paratuberkulózou}

Mykobakteriální enteritídy u skotu označované jako paratuberkulóza mohou být vyvolány kromě Mycobacterium avium subspecies paratuberculosis i jinými poddruhy, nebo variantami $M$. avium, které však mají menší epizootologický význam. Neúspěchy při tlumení paratuberkulózy skotu jsou mnohdy zaviněny mylnou představou, že hlavním zdrojem této nákazy je výhradně dospělý skot v preklinické a klinické fázi onemocnění starší 18 měsíců. $Z$ výsledků našeho studia patogeneze vyplynulo, že telata nakažená paratuberkulózou v prvních týdnech po narození mohou být významným zdrojem infekce a to již ve stáří několika měsíců. V letch 2000- 2003 bylo vyštřeno 18 chovů s cekovým počtem 3620 zvířat,v nichž byla zjištěna bovinní paratuberkulóza $\mathrm{v}$ šesti chovech. $\mathrm{V}$ chovech kde se nedodržovala důsledně protinákazová opatření bylo zjištěno masivní vylučování mykobakterií původce paratuberkulózy trusem u 7,6-80 \% vyšetř̆ovaného mladého skotu a to již ve stáři 4-6 měsíců.

V současné době se většinou považuje bakteriologické vyšetřování trusu pomocí kultivace za nejspolehlivější metodu k intravitální diagnostice paratuberkulózy skotu. Přitom nedostatkem kultivačního vyšetření je značně dlouhá doba nutná ke konečnému posouzení vyšetřovaného vzorku. V posledních letech se nám uvedený nedostatek podařilo z velké míry odstranit zavedením separační bakterioskopické metody, při níž bylo možno prokázat vylučovatele mykobakterií paratuberkulózy v chovech skotu nakažených touto nákazou do několika dnů po odběru vzorku trusu. Uvedený průkaz mykobakterií při separační bakterioskopii bylo možno doplnit i metodou molekulární biologie-PCR k určení sekvence IS 900. O spolehlivosti uvedené metody svědčí i výsledky srovnávacích testů, při kterých bylo dosaženo 90 \% citlivosti při separační bakterioskopii ve srovnání se standardní kultivací doporučovanou OIE.

\section{References}

Mc FADDEN JJ, BUTCHER PD, CHIODINI R, HERMON-TAYLOR J 1987: The use of DNA probes identifying restriction fragment length polymorphisms to examine the Mycobacterium avium complex. Mol Microbiol 1: 283-291 
SAXEGAARD, F 1990: Experimental infection of calves with an apparently specific goat-pathogenic strain of Mycobacterium paratuberculosis. J Comp Pathol 102: 149-156

SAXEGAARD F, BASS I 1988: Relationship between Mycobacterium avium, Mycobacterium paratuberculosis and , Wood pigeon mycobacteria“ APMIS 96: 37-42

OIE, World Organization for Animal Health, Manual of Standards for Diagnostics Test and vaccines, fourth Edition, Paris 2000.

Metodický návod č.6/2001 k prevenci, diagnostice a zdolávání paratuberkulózy, Ře/1482/01, Státní veterinární správa České republiky

PAVLAS, M 1990: Biologické vlastnosti kmenů mykobakterií izolovaných u skotu z chovů s klinickou paratuberkulózou. Vet Med (Praha) 35: 523-528

PAVLAS, M 1990: Alergická a serologická diagnostika paratuberkulózy skotu. Vet Med (Praha) 35: 577-585

PAVLAS M, HANZLÍKOVÁ M, ŠTIKA V, PAVLÍK, I 1997: Incidence, diagnostics and control of paratuberculosis of cattle in Czech and Slovak Republics (in Czech). Slov Vet Cas, 4: 184-187 